EASTERN REVIEW 2020, T. 9

\author{
Anastasiya Ilyina \\ (iD) https://orcid.org/0000-0002-5786-0365 \\ Belarusian Institute for Strategic Studies, Vilnius, Lithuania \\ Biełsat TV, Warszawa, Polska \\ e-mail: anastasiya.ilina@gmail.com
}

\title{
Russia's hybrid invasion in Belarus during the presidential election campaign 2020
}

\begin{abstract}
There are various instruments for Russia to have influence on its neighbours, such as using opinion leaders (authorities), intellectuals, and journalists to create a favourable informational context or to place the ordered materials in the media so as to have an impact on public opinion. These are the types of information attacks that can lead to the loss of statehood or the substantial limitation of sovereignty. This hybrid aggression strives to precisely this result. The main questions are: how the Russian information space, mud-slinging and troll farms functioned in Belarus during the presidential election? How the fake news which is produced in Russia impacts societies? Which political scenarios appeared in Belarus following Russia's informational influence? It is a fact that today the Russian authorities use tools of fake news and propaganda; combined with the extra possibilities of social media. The appearance of fake news is connected with national safety because they jeopardize democratic institutions, lead to the radicalization of society, and change the balance of authority. In the research, the methodologies were used from the sociology of communication, political science and content analysis.
\end{abstract} media.

Keywords: fake news, an Internet shutdown, information warfare, a hybrid war, new

\section{The Russian's hybrid invasion and informational impact on Belarus}

The issue of Russian's hybrid invasion and informational impact on Belarus is hugely relevant. That is because Russia was an active actor in the internal political changes in Belarus during the presidential election campaign of 2020 and the post-election period. It's worth mentioning that previous research was devoted to the waves of disinformation and propaganda launched by Russia to try 
and influence public opinion in Belarus. Firstly, the research of Andrei Yeliseyeu Fundamental Shifts in Anti-Belarusian Disinformation and Propaganda: Analysis of Quantitative and Qualitative Changes (EAST Center, April 2019) and Sputnik Belarus's Propaganda and Disinformation: Narratives, Methods, and Trends (EAST Center, March 2020); secondly, the collaborative study by Vasil Naumau, Anastasiya Ilyina, Katsiaryna Shmatsina entitled The stalemate of deepened integration: analysis of the Russian anti-Belarus disinformation campaign in 2019 (College, 2020); thirdly, the research of the International Strategic Action Network for Security by Andrei Yelisieyeu (Bela)Ru(s)sian propaganda: three key ways to discredit Svetlana Tikhanovskaya (2020), by Alexey Kovalev, Yan Avesyushkin How the Russian state media rescued Belarusian broadcasters from political pluralism (2020) and Maria Avdeeva's The Kremlin's Influence Operations: Working Out Countering Mechanisms for Eastern Partnership Member States (2020) fourthly, the analytic reports of the Atlantic Council and Chatham House. Also, I would like to mention the $4^{\text {th }} / 2020$ volume of New Eastern Europe which is launched by The Kremlin's hybrid war. Moreover, we need to take into account the books of Ukrainian authors Hybrid war by Yevgen Magda (2015) and The war of Reality by Dmytro Kuleba (2019). Definitely, the list of research about fake news is quite extensive, but I focused on the sources that deal with the region of Eastern Europe.

In my research, I would like to establish how Russia has actively been using the instruments of information and hybrid warfare in Belarus during the presidential election and especially the post-election period. The research hypothesis is that the Russian hybrid invasion is a continuation of Russian aggression against Georgia in 2008 and Ukraine in 2014. In this article, I provide analysis of existing relevant reports and research on the degree of misinformation and propaganda in Belarus as well as analysis of the content of selected articles from journalists, experts, and bloggers.

Internet connectivity was significantly disrupted in Belarus on election day and the following days. Belarusians have faced the reality of how to meet new challenges. There were two main reasons for the Internet's shutdown: to prevent alternative vote counting - Tikhanovskaya's united campaign called on voters to send ballot pictures to the Voice platform, where almost a million voters registered; and to prevent communication and coordination after the election. The internet and new media have never played such an important role as during this year's presidential campaign. First, alternative candidates actively used social networking during the campaign. In particular, the candidates Viktor Babariko and Valery Tsepkalo were promoted in the new media. The style of work of the SMM-team was similar to the work of a bot farm. While the media face of Valery Tsepkalo on social networks was his wife Veronika. Also in the first days after the election, thanks to telegram channels, the coordination of actions was carried out; and most importantly in the situation where independent media 
was blocked, telegrams became a source of information for TV-channels (Belsat TV, TV Rain, Current time TV) as well. However, social media have traditionally been good places for fake news, bogus stories or Russian trolls.

In support of Lukashenko, the activity of pseudo-accounts in the comment sections of popular sites and social networks has noticeably intensified in the past couple of months. Tens and hundreds of "commentators" with the same type of posts suddenly swoop on individual news reports and notes. Even more interesting, according to researcher Andrei Yeliseyev, is that the largest of the groups of bots operating under the post of Krivosheev consistently promote the posts of Russian MP Leonid Slutskyi, head of the State Duma Committee on International Politics, which legitimized the Crimean referendum in 2014 by bringing in marginal European politicians.

\section{Not only soft power}

Ten days before elections, Belarusian authorities announced a criminal investigation against 33 mercenaries of Wagner PMC, a Russian security contractor involved in nefarious activities in places such as Ukraine, Syria, and Libya. A unit of the Belarusian KGB arrested the Russians in a sanatorium near Minsk, the Belarusian capital. Belarusian authorities claimed that 170 other militants are still at large across the country. It was a good picture for the state media, after the elections, all 32 mercenaries of Wagner PMC were transferred to Russia.

On the evening of the vote count, during a peaceful protest, Russian military correspondent Semyon Pegov was detained among the protesters. Media photos show Pegov being dragged by a Belarusian police officer into a police vehicle in an unconscious state. A week before the election, Pegov claimed on a Russian propaganda show, hosted by Vladimir Solovyev, that there were some training bases for nationalist militants in the east of Belarus, similar to the Ukrainian "Right Sector".

Following the announcement of the results of the vote and the lengthy protests, Lukashenko continues to manipulate the Russian threat. However, despite the strikes of employees, it is the Belarusian state TV channels that have adopted a rhetoric that Belarusian-Russian relations are under threat: as Lukashenko's opponents are ready to leave the CSTO, the Eurasian Union and the CIS. At the same time, telegram channels show that troops of the Russian National Guard, without identification markings, have already entered Belarus.

Pro-Russian forces in Belarus have begun to act and deliver plan B. The Kremlin has begun to use an alternative plan in case Lukashenko does not control the situation in the country. Among the main actors - The Republican Party of Labor and Justice (RPTS), The Liberal Democratic Party of Belarus (LDPB), and 
the Civil Initiative "Union". Alexander Lukashok from RPTS whilst on-air on "Russia 1" unambiguously stated, they say, that healthy (read: pro-Russian) forces "will definitely join the game tomorrow". Oleg Gaidukevich, head of the LDPB and member of the Belarusian parliament, issued a statement on the creation of the "People's Patriotic Movement of Belarus". He stands for "the unconditional preservation and development of the Union with Russia and the CSTO" and the convening of an extraordinary parliamentary session. It was announced that "The People's Patriotic Movement is beginning to prepare and conduct constituent assemblies in all regions of the country and in Minsk". One of the points is to strengthen the role of the parliament. The most interesting thing is that in past elections Gaidukevich was Lukashenko's confidant.

Moreover, the Civil Initiative "Union" issued a statement, which says that in order to overcome the political crisis, a dialogue of the authorities "with all social movements of the country" is necessary. True, after a couple of sentences, there was clarification: such a dialogue should, first of all, go with civil forces and movements "united by a common Russian culture".

After more than 70 days of protests, Lukashenko's meetings with political prisoners and the release of some of them, the Union Civic Initiative has stepped up and announced the creation of a party which supports integration with Russia, and even recognizes the independence of South Ossetia and Abkhazia. This tendency is very dangerous because Lukashenko announced the Constitutional reform, and Russia is interested in this reform too, trying to expand the role of parties in the Belarusian parliament. Again we can see the Russian hybrid invasion because it will try to lead the pro-Russian elements into the Belarusian Parliament on the model of the Ukrainian example (oligarch Viktor Medvedchuk and his party Opposition Platform for Life). The second challenge could be Russia's use of its "sleeping network", which covers the whole of Belarus (sites that promote the Russian world, or the same civic initiatives that receive Russian grants) (College of Europe, 2020).

At the same time, Lukashenko and the state Belarusian media continue to warn of the "Western threat". In the situation when workers of state media (National State Television and Radio Company of Belarus) go on strike, Russia sends its professionals to replace these strikers.

According to the research of the International Strategic Action Network of Security (iSANS), Russia has begun a hybrid operation to establish control over the media, public space, security forces and the administrative institutions. Besides the Russian specialists who were invited to the country by Alexander Lukashenko to replace the Belarusian workers on strike, there has also been the activation of pro-Russian political elements of the network of Russian influence in Belarus - including the creation of the "People's Patriotic Movement of Belarus" by LDPB leader Oleg Gaidukevich and others. The experts of iSANS drew attention to the active coverage and support of all movements and statements of Valeriy 
Tsepkalo by RIA Novosti, which de facto already serves as his press service. iSANS specifies who came to Belarus as a Kremlin landing party. On Tuesday, August 18, a mobile television station (PTS) of the RT channel (MIA Rossiya Segodnya) was spotted in Minsk. On Wednesday, August 19, Internet users began to publish photos of the propagandist Irada Zeynalova in Minsk. The specialists from Russia were brought to state TV channels BT and ONT to replace striking and retired journalists and technical staff. Thus, television in Belarus, which was previously under the full control of the Belarusian authorities, has already been taken under Russian control. High-ranking curators from Moscow were also sent to the Sputnik Belarus office on August 19 with the task of "unifying the presentation of information" on the model of the Ukrainian agenda in 2014-2020. We can already see the first results of this work - wild propaganda videos that were launched on another state channel, STV, with the aim of demonizing Svetlana Tikhanovskaya. In fact, now the role of state TV channels is reduced to inciting civil conflict in Belarus. The posters and posts of a similar nature appeared on the streets of Belarus and on social media. Moreover, there have occurred "for Bat'ka" rallies, organized by activating pro-Russian forces. Their main aims are the formation of the Belarusian version of the "anti-Maidan", structuring the activities of the pro-Russian political wing on the territory of Belarus, juxtaposing the East and West of the country.

\section{The European's position in relation to the Belarusian election}

Against this background, Europe's position "that the situation in Belarus is exclusively an internal conflict" looks faded. The consequences of this position may be stimulating direct contacts between the EU and Russia on the "Belarusian issue". Some EU officials have already expressed their readiness to take into account the interests of Moscow, and the influence of politicians who are inclined to solve the "Belarusian issue" not in Minsk, but in Moscow, is growing more and more. The strategic interest of the EU in Belarus is the absence of political conflict on its borders, the observance of human rights at an acceptable level, and the preservation of formal sovereignty. Russia's strategic interest is in keeping Belarus in its orbit and, at least, the status quo in bilateral relations (SG, CSTO, EAEU). The manoeuvring schemes between the West and Russia, which were used in 2008-2020, will not work. All this makes the positions of the officials in Minsk extremely vulnerable even in the short term. And this is without taking into account the sanctions and the economic consequences of the EU decision. But what is important is that the leader of democratic Belarus, Svetlana Tikhanovskaya, had meetings with two European leaders: President of France Emanuel Macron and Chancellor of Germany Angela Merkel, which gives her subjectivity in the international arena. 
Russia recognizes the presidential election as legitimate and Alexander Lukashenko as the winner. This was stated by Russian President Vladimir Putin in an interview broadcast on the program "News on Saturday" on TV channel "Russia-1". Prior to this statement, it was reported that Russia prepared a police force to assist Lukashenko if necessary. Responding to this, German Chancellor Angela Merkel said that she hopes that Russia is not using the law enforcement reserve created by Moscow. The Western countries still declare that a key task for the European Union (EU) is to help the Belarusian people without providing a pretext for further violence and Russian intervention. In addition, there are major anxieties about agreements with Russia, namely that the fate of the country will be decided without the participation of Belarus, at the level of Putin and Western negotiators. As a result, Belarus may become more dependent on Russia, losing all or part of its sovereignty. I remark that Putin supports Lukashenko as he supported Bashar al-Assad in Syria or Nicolás Maduro in Venezuela because he understands that Lukashenko will continue the integration process (I mean fistful diplomatic and economic help but also with a readiness for military support). It is clear that the vision that Lukashenko is the last bastion before Russification and the absorption of Belarus by Russia was completely false. The United States and Russia had competing geopolitical interests regarding Ukraine, but that was not the case with regard to Belarus. Steven Pifer also underlined that "there was no push in Minsk to join the European Union, and zero Belarusian interest in NATO" (Atlantic Council, 2020). This is characteristic of the Belarusian protest 2020 that the protest is definitely not for geopolitical choice as it was in Ukraine; it is for the right to have free and fair elections. For instance, the protestors still do not use the flags of the EU, U.S., or Russia, except during the rallies of regime supporters. This is a protest about democracy.

Lukashenko is drawing attention to the north-west corner of Belarus, singling out the city of Grodno near the border with Poland and Lithuania as a supposed target for Western efforts at destabilization. All this feeds his narrative that Belarus is in danger from NATO and the West who are supposedly both stirring up the protests and seeking to exploit disorder - and that this danger extends to possible military clashes (Chatham House, 2020).

\section{The Kremlin's strategy}

Some experts' voices say that the Kremlin will not use military intervention to support Lukashenko. This is in part due to the fact that Russia is already providing assistance to Lukashenko: by offering its media resources, public criticism of Tikhanovskaya and the Coordination Council, as well as political statements demanding non-intervention of the European countries into Belarusian 
affairs. All this is not because the Kremlin is interested in keeping Lukashenko in power. It's because now any support increases Lukashenko's debt to the Kremlin. If Lukashenko remains in power, he will be forced to pay off this debt for the rest of his term. Military intervention is directly opposite to what the Kremlin wants. After Lukashenko lets the Kremlin's operating managers into his realm, Putin has the opportunity to take control over both the civil and military administration in Belarus without any use of military forces. The experts of iSANS suggest considering the following scenario of the Russian impact on Belarus:

1. Non-intervention of the West and discredit of any European support to Belarusian society to make sure no Western alliance will be built around the demands for new and fair elections. This line is being pursued by Sergey Lavrov and the Kremlin's media.

2. Imposing a change in the composition of the Coordination Council: to include a group of high-profile politicians, loyal to the Kremlin instead. Such people on the Coordination Council will clearly ensure the preservation of relations between Moscow and Minsk in the Kremlin's interest. These people will completely fit Putin's expectations should Lukashenko be 'hospitalized' (thus making new elections inevitable). Removing Tikhanovskaya from the scene or completely side-lining her.

3. Driving Lukashenko deeper into debt to Kremlin.

4. Sending more Moscow media workers, political strategists, FSB groups, cybersecurity experts (etc.) to Minsk to seize control over all the state apparatus (regardless of whether Lukashenko remains in power in the next three months or not).

5. Shaping an attractive image of further integration with Russia within Belarusian society (Morozov, 2020).

I suggest considering the following scenarios for the development of the Belarusian political crisis. The pessimistic scenarios imply that Lukashenko remains in power, Western countries don't recognize the election result but de facto continue to be in contact with the usurper. First of all, Lukashenko is being harassed by personal sanctions. The next negative scenario is that Lukashenko remains on his post for a transitional period, up to one year (something like that was offered to the former Ukrainian President Viktor Yanukovych in 2013). The Belarusian regime uses this time to hold a referendum to legalize or withdraw financial savings. One of the negative scenarios could be that new elections are scheduled, in which the winner is not an open but a pro-Russian candidate. The realistic scenario could be some hybrid scenario. And the last - the optimistic scenario that a new election is scheduled as a result of which the independent candidate wins, holds parliamentary and local elections, returns to the 1994 Constitution (given that some experts compare the events in Belarus with the Ukrainian Maidan 2004, such a scenario is possible in a few years).

Whatever scenario unfolds, today we can conclude that due to protest against the false result of the presidential election the nation has awoken (thousands of 
people accept national symbols and struggle for the democratic values). One more result of the Belarusian revolution is the strengthening of the working movement (Despite the repression, dozens of factories joined the national strike). And another interesting thing is that this revolution has a women's face. I mean that not just the main opponent was a woman, Svetlana Tikhanovskaya, or her united campaign consisted of women but that the Belarusian women and girls actively organized women's chains of solidarity and marches against police violence and election fraud. This can lead to changing the role of women in Belarusian society, to developing women's empowerment in political leadership and policymaking.

In the situation of Lukashenko keeping his power, the main challenges will be the huge waves of emigration from the country, first of all, competitive and highly-skilled workers. And the most obvious risk is that the Belarusian regime will remain a military dictatorship with signs of totalitarianism. And it is not only a matter of strengthening the powerful repressive apparatus, but achieving total control of the Internet and the destruction of independent media and the public sector.

In conclusion, it is noted that the Kremlin does not intend to release Georgia, Ukraine, and other post-Soviet countries, even after the military conflicts in the territories. The Kremlin does not intend to leave Belarus. Although the hot stage of the conflict in Belarus has not begun: Russia has not openly introduced an army. Vladimir Putin is using the tactics of "creeping occupation", which has been actively deployed through the tools of information warfare, the involvement of Russian propagandists, and the promotion of pro-Russian political initiatives. All these activities are elements of a hybrid invasion, honed as the Kremlin reviewed the lessons after Georgia and Ukraine. These lessons alas were not learnt by the Belarusian society regardless of the fact that it does assess the political changes in their own country through a geopolitical prism.

\section{References}

Atlantic Council. 2020. Is Putin about to make a costly mistake in Belarus?, https://www. atlanticcouncil.org/blogs/ukrainealert/is-putin-about-to-make-a-costly-mistake-in -belarus/ (accessed 11.02.2021).

Avdeeva, M. 2020. Kremlin's Influence Operations: Working Out Countering Mechanisms for Eastern Partnership Member States, https://isans.org/articles-en/kremlinsinfluence-operations-working-out-countering-mechanisms-for-eastern-partnershipmember-states.html (accessed 11.02.2021).

Chatham House. 2020. By Inventing Military Threats, Lukashenka Is Playing with Fire, https://www.chathamhouse.org/2020/08/inventing-military-threats-lukashenkaplaying-fire?fbclid=IwAR1IwDRaQQ640SEzqYEjtFLJ4CjiVkUVQwrBF9D0qIj0 bdEhlsr2khnA7bg\&utm_content=belarus-lukashenka-war\&utm_medium=organicsocial\&utm_source=facebook.com (accessed 11.02.2021). 
College of Europe. 2020. THE STALEMATE OF DEEPENED INTEGRATION: ANALYSIS OF THE RUSSIAN ANTI-BELARUS DISINFORMATION CAMPAIGN IN 2019, https:/www.weasa.org/the-stalemate-of-deepened-integration-analysis-of-therussian-anti-belarus-disinformation-campaign-in-2019/?fbclid=IwAR1C9cr1CWp9em_fLrbF106cVmZi8m8-85qiWFXQs-qgI_IZHftQcxVfxg (accessed 11.02.2021).

EAST Center. 2019. Fundamental Shifts in Anti-Belarusian Disinformation and Propaganda: Analysis of Quantitative and Qualitative Changes, https://east-center.org/fundamentalshifts-in-anti-belarus-disinformation-and-propaganda/ (accessed 11.02.2021).

EAST Center. 2020. Sputnik Belarus's Propaganda and Disinformation: Narratives, Methods, and Trends, https://east-center.org/sputnik-belarus-propaganda-anddisinformation-narratives-methods-and-trends/ (accessed 11.02.2021).

Kovalev, A., Avesyushkin, Y. 2020. How the Russian state media rescued Belarusian broadcasters from political pluralism, https://isans.org/articles-en/how-therussian-state-media-rescued-belarusian-broadcasters-from-political-pluralism.html (accessed 11.02.2021).

Kuleba, D. 2019. Viyna zareal'nist': yak peremagati u sviti feykiv, pravd i spil'not. Kiïv: Knigo.

Magda, Ye. 2015. Gibridnaia voŭna: vyzhit'i pobedit'. Khar'kov: Vivat Publishing.

Morozov, A. 2020. Kremlin operation to intercept control over the situation in Belarus, https://isans.org/columns-en/kremlin-operation-to-intercept-control-over-thesituation-in-belarus.html (accessed 11.02.2021).

New Eastern Europe - A bimonthly news magazine dedicated to Central and Eastern European affairs. Issue 4/2020 The Kremlin's Hybrid War, https://neweasterneurope.eu/ product/issue-4-2020-the-kremlins-hybrid-war/ (accessed 11.02.2021).

Yelisieyeu, A. 2020. (Bela)Ru(s)sian propaganda: three key ways to discredit Svetlana Tikhanovskaya, https://isans.org/columns-en/belarussian-propaganda-three-key-waysto-discredit-svetlana-tikhanovskaya.html (accessed 11.02.2021). 